\title{
Situations of Domestic Violence against Children and Adolescents in a Northeastern Brazilian Capital
}

\section{Eliane Santos Cavalcante ${ }^{1 *}$, Francisco Arnoldo Nunes de Miranda ${ }^{2}$, Lannuzya Veríssimo e Oliveira ${ }^{1}$, Glauber Weder dos Santos Silva², Gustavo Ávila Dias3 ${ }^{3}$, Romeika Carla Ferreira de Sena², Suerda Lillian da Fonseca Lins ${ }^{2}$, Cleonice Andréa Alves Cavalcante ${ }^{1}$, Izaura Luzia Silvério Freire ${ }^{1}$, João Evangelista da Costa ${ }^{2}$}

${ }^{1}$ Health School, Federal University of Rio Grande do Norte, Natal, Brazil

${ }^{2}$ Nursing Department, Postgraduate Program in Nursing, Federal University of Rio Grande do Norte, Natal, Brazil

${ }^{3}$ Natal Health City Department, Natal, Brazil

Email: *eliane@es.ufrn.br

How to cite this paper: Cavalcante, E.S., de Miranda, F.A.N., Veríssimo e Oliveira, L., dos Santos Silva, G.W., Dias, G.Á., de Sena, R.C.F., da Fonseca Lins, S.L., Cavalcante, C.A.A., Freire, I.L.S. and da Costa, J.E. (2016) Situations of Domestic Violence against Children and Adolescents in a Northeastern Brazilian Capital. Open Journal of Nursing, 6, 633-642.

http://dx.doi.org/10.4236/ojn.2016.69067

Received: July 23, 2016

Accepted: August 29, 2016

Published: September 1, 2016

Copyright $\odot 2016$ by authors and Scientific Research Publishing Inc. This work is licensed under the Creative Commons Attribution International License (CC BY 4.0).

http://creativecommons.org/licenses/by/4.0/

\section{Abstract}

Objective: To describe the epidemiological profile of children and adolescents who are victims of domestic violence. Method: This is a cross sectional and descriptive study, following a quantitative approach, conducted from September to December 2013, at the SOS CHILD service, in the city of Natal, Rio Grande do Norte, Brazil. The research protocol was approved by CEP/UFRN under CAAE 0166.0.051.000-11. Results: In the analysis of 69 children, the results were presented from three points of view: 1$)$ the victim-female (56.5\%), aged one to 11 years old (66.7\%) and lived with one of the parents $(43.5 \%) ; 2)$ the abuser-female $(60.9 \%)$ in the $14-23$ years old and $34-43$ years old, with the same percentage (24.6\%), history of alcohol use and abuse $(42.0 \%)$, the mother was the one who attacked the most $(34.7 \%)$; 3$)$ types of violence, among the physical ones, the most frequent were slaps (43.2\%) and punches (18.9\%); the prevalence, among the psychological violence, were curses (35.4\%) and abuse (27.8\%); negligence, omission of care (73.5\%), deprivation of care for personal appearance (18.4\%); among sexual violence: sexual caresses (57.1\%) and forced sex (42.9\%). Conclusion: Children and adolescents placed in an unfavorable social-economic context, under the care of mothers with a history of use and abuse of alcohol and other drugs, are more vulnerable to intra-domiciliary violence.

\section{Keywords}

Exposure to Violence, Domestic Violence, Child Health, Adolescent Health 


\section{Introduction}

The violence, understood as the violation of human rights, is considered as a global, current, complex, polysemic phenomenon, and occurs in a heterogeneous and asymmetrical way, practiced by individuals against other individuals. It assumes different contexts and different impacts on the social, political and cultural relations [1]. On the one hand, the media and its expressive vehicles report about poor living conditions, vulnerability and human security; on the other hand, after a few minutes of sensationalism, the suffering of the victims and their families are doomed to mediatic oblivion [2].

Epidemiological data indicate a significant increase in morbidity and mortality resulting from violence in recent decades, both in industrialized countries, such as Brazil [3]. In the spectrum of the victims of all kinds of violence committed by family and non-family members, there are children and adolescents, emerging as one of the most exposed and vulnerable to violations of their rights, directly and indirectly affecting their physical, mental and emotional health [4].

Violence against children and adolescents in Brazil is not a state, but rather a process that takes many faces and nuances, and is present in every action or omission capable of causing injury, damage and inconvenience to the full development of children and adolescents [5]. In other words, one can say that occasional cases of violence to these people could be due to an asymmetric and unequal power relationship, manifested by physical force, by economic or political power, for domination and family or generational oppression. This violence can come to configure also structurally, that is, the implementation of educational, health or economic policies which don't offer any kind of contribution or even prevent the growth and development of children [4].

The scenario or itinerary of violence often begins within domestic space and passes through schools and their surroundings, the community and other institutions, as terminating sources and conditions that produce violence. The physical, social, emotional and cognitive burden of the victims may permanently compromise children and adolescents. The perverse effects may incur construction of a violent playback circle and feedback, because it is recognized that children and adolescents tend to reproduce what they live through their play, attitudes and learning, corroborating other pairs to become the main victims of violent actions [4] [6].

In Brazil, since 2001, the notification of violence involving children, adolescents, women and elderlies has been mandatory in order to provide visibility to the problem, and characterize its magnitude, size, specificity and complexity to fight this problem. It was implemented by the Ministry of Health through the Diseases Notification Information System-SINAN (Sistema de Informação de Agravos de Notificação in Portuguese) in 2009 [7]. It is noteworthy that the focus of this study concerns the violence of children and adolescents.

This type of measure taken by the Unified Health System in Brazil contributes to the formulation of public policies with inter-sectorial, inter-institutional, interdisciplinary and networking actions. For this, the collecting must be universal, continuous and compulsory in situations of violence [8]. Notifying violence should be understood as an 
instrument that goes beyond the mere collection of epidemiological information. It should, therefore, be seen as one of the instruments to guarantee rights, to preserve the health and life and to articulate and integrate the social protection and the comprehensive health care network, following the line of health care [4].

A characteristic of the domestic violence against children and adolescents is the omission of parents, relatives or any other people who are responsible for these individual's custody, which may cause damage or suffering - physical, sexual or psychological-also negligence (the most frequently cause of notifications reported), and falls unequally on race, gender, age and other factors. It is considered as an act rooted Brazilian culture historically proven. However, this phenomenon lacks a more comprehensive statistic, a significant fact [9].

It is clear that the seriousness and scope of this issue in so far as this study seeks to better understand the phenomenon in order to support decision-making aimed at prevention and control, in addition to supporting other studies. From this premise, based on experience and coexistence in the Child and Adolescent Protection Service-SOS CHILD, which belongs to the State Foundation for Children and Adolescents of Rio Grande do Norte, Brazil (FUNDAC/RN), the question is: What are the epidemiological characteristics of children and adolescents victims of violence assisted at the emergency rooms in the city of Natal and referred to children and adolescents' protection agencies?

In this sense, the present study aimed to describe the epidemiological profile of children and adolescents victims of domestic violence reported by SOS CHILD.

\section{Method}

This is an epidemiological, descriptive and cross-sectional study. The descriptive epidemiology analyzes how the incidence (new cases) or prevalence (existing cases) of certain disease or condition related to health varies according to certain characteristics, such as gender, age, educational attainment and income, among others [10].

The research was developed with all the children and adolescents attended by the SOS CHILD Service, in the city of Natal, capital of Rio Grande do Norte, Brazil, who were victims of domestic violence, from September $15^{\text {th }}$ to December $31^{\text {st }}, 2013$. To characterize the study population, the WHO classification criteria was adopted [11], in which the child's age goes from zero to less than 10 years and adolescence goes from 10 to 19 years old.

In this sense, the following inclusion criteria were established: children and/or adolescents from zero to 19; residents in the metropolitan area of Natal/RN; referred and treated at the SOS CHILD in the second half of 2013; victims of domestic violence. Unconfirmed cases and individuals who refused to participate were excluded. Therefore, the sample consisted of 69 subjects, included in a non-probabilistic way, by convenience.

The data were collected by two instruments, namely: 1) information contained in the guides that accompany the victims and in the register of spreadsheet reports used and treated at SOS CHILD; 2) and a form applied to the child, when possible, and to the legal guardians/companion of the victim, which, besides complementing the information 
on the victim, his/her family and the aggressor, gave information about the circumstances of the violence. The data were collected after the researchers provided detailed information on the investigation and signature of the Informed Consent Form by the parents or legal guardians.

It was submitted to the Research Ethics Committee of the Federal University of Rio Grande do Norte (CEP-UFRN) protocol number 139/2011, CAAE number 0166.0.051.000-11, in accordance with the provisions of Resolution number 196/1996 of the Brazil National Health Council (CNS), valid at the development of the research. However, the current resolution is number 466/2012/CNS.

For constructing the databases, the statistical treatment of the software Microsoft Office Excel $2013^{\circledR}$ was used to descriptively summarize the data with absolute frequencies and percentiles, presented by tables.

\section{Results}

In the studied period, the SOS CHILD of Natal/RN tended 69 cases of violence against children. After data analysis, it was observed that the impact of violence on children and adolescents are presented under three points of view: the victim, the offender and the types of violence. It is noteworthy that the boundaries among the causes that support the violence are so precarious that they are didactically presented in order to clarify and understand as a provisional and recent result of the child and adolescent victimization process.

The victim-Table 1 shows that most of the victims of domestic violence were female $(56.5 \%)$, mostly aged from one to 11 years $(66.7 \%)$, with minimum age of two days, and maximum age of 16 years. The majority attended school/kindergarten (52.2\%). They lived with one of the parents (43.5\%), in Natal, and the West Zone had the highest number of notifications (44.9\%).

The aggressor-Table 2 shows that most of the aggressors were female (60.9\%), with predominant age groups of $14-23$ years and $34-43$ years, with the same percentage (24.6\%), with educational attainment of no literacy/basic education (65.2\%), unemployed (53.6\%), with a history of alcohol use and abuse (42.0\%). As for the kinship with the victims, the mother was the most frequent (34.7\%).

Types of violence-Table 3 shows the types of violence reported by SOS CHILD. The physical violence (62.3\%), followed by psychological (60.8\%), was the most frequent. Among physical violence, the most frequent were slaps (43.2\%) and punches (18.9\%). Concerning psychological violence, the most frequent were offenses (35.4\%) and abuse (27.8\%). Among the most common disregards were omission of care (73.5\%) and deprivation of care for personal appearance (18.4\%). The reported sexual violence was submission to sexual caresses (57.1\%) and forced sex (42.9\%).

\section{Discussion}

According to the World Report on Violence and Health [12], researches about the subject showed that cases of abuse occur more intensively in poor areas where there is little 
Table 1. Characterization of the victims of domestic violence attended at SOS Child, Natal/RN, Brazil, 2016.

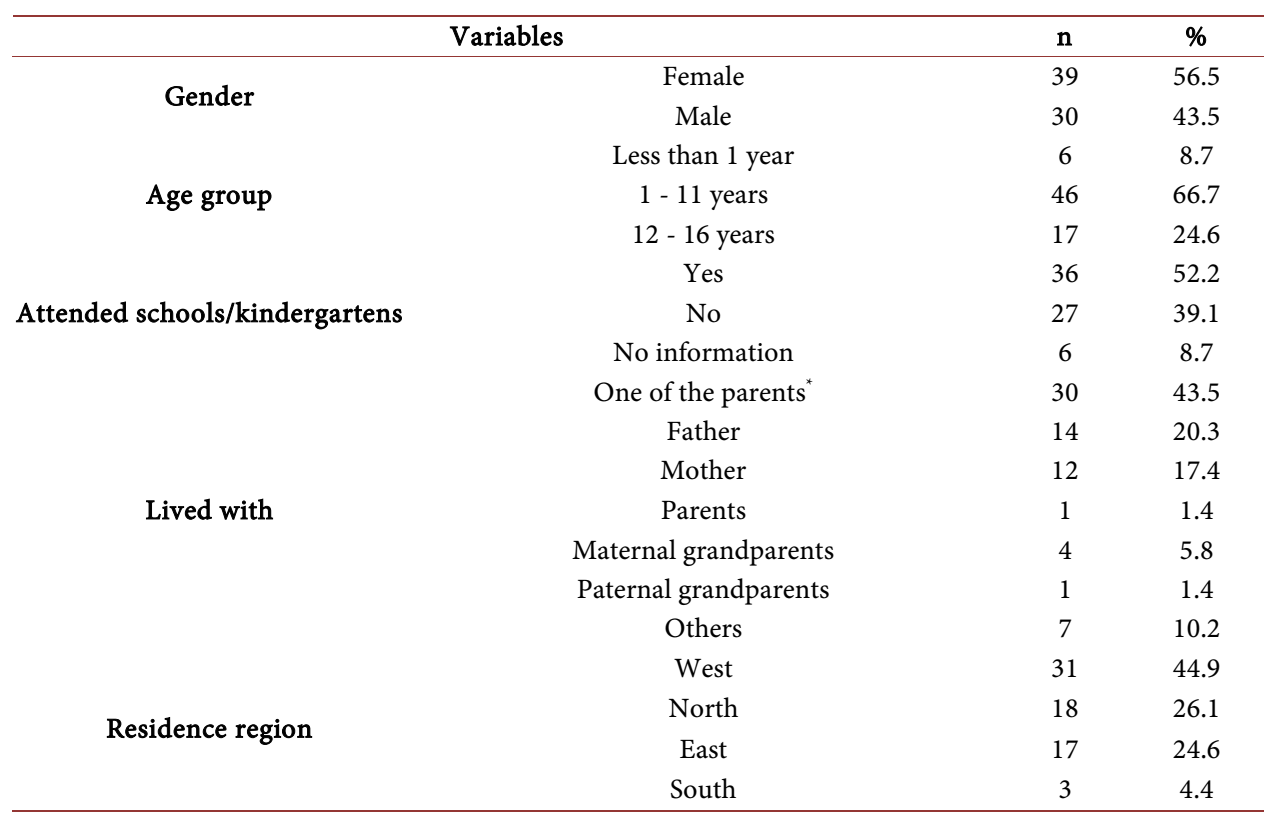

Source: research database.

Table 2. Characterization of the domestic violence victims' aggressor attended at SOS Child, Natal/RN, Brazil, 2016.

\begin{tabular}{|c|c|c|c|}
\hline \multicolumn{2}{|r|}{ Variables } & $\mathbf{n}$ & $\%$ \\
\hline \multirow{4}{*}{ Gender } & Female & 42 & 60.9 \\
\hline & Male & 27 & 39.1 \\
\hline & $14-23$ years & 17 & 24.6 \\
\hline & $24-33$ years & 16 & 23.2 \\
\hline \multirow[t]{4}{*}{ Age group } & $34-43$ years & 17 & 24.6 \\
\hline & $44-53$ years & 14 & 20.3 \\
\hline & Over 54 years & 5 & 7.3 \\
\hline & Illiterate/Incomplete elementary school & 45 & 65.2 \\
\hline \multirow{3}{*}{ Educational attainment } & Complete elementary school/Incomplete high school & 13 & 18.9 \\
\hline & Complete high school/Incomplete college & 10 & 14.5 \\
\hline & Complete college & 1 & 1.4 \\
\hline \multirow{4}{*}{ Occupation } & Yes & 32 & 46.4 \\
\hline & No & 37 & 53.6 \\
\hline & Use and abuse of alcohol & 29 & 42.0 \\
\hline & Use and abuse of drugs & 15 & 21.7 \\
\hline \multirow{6}{*}{ Risk factor } & Weakened family relationship & 8 & 11.6 \\
\hline & Psychological disorders & 7 & 10.2 \\
\hline & Jealous & 3 & 4.3 \\
\hline & Others & 7 & 10.2 \\
\hline & Mother & 24 & 34.7 \\
\hline & Father & 18 & 26.1 \\
\hline \multirow{4}{*}{ Kinship with the victim } & Stepfather/Stepmother & 12 & 17.4 \\
\hline & Uncle/Aunt & 6 & 8.7 \\
\hline & Grandmother/Grandfather & 4 & 5.8 \\
\hline & Others & 5 & 7.3 \\
\hline
\end{tabular}

Source: research database. 
Table 3. Characterization of the domestic violence reported by SOS CHILD, Natal/RN, Brazil, 2016.

\begin{tabular}{|c|c|c|c|}
\hline & Variables & $\mathbf{n}$ & $\%$ \\
\hline \multirow{3}{*}{ Types of violence ${ }^{*}$} & Physical & 43 & 40.2 \\
\hline & Psychological & 42 & 39.3 \\
\hline & Negligence & 17 & 15.9 \\
\hline \multirow{5}{*}{ Type of physical violence ${ }^{*}$} & Sexual & 5 & 4.7 \\
\hline & Slaps & 32 & 43.2 \\
\hline & Punches & 14 & 18.9 \\
\hline & Pushes & 12 & 16.2 \\
\hline & Hair pulling & 3 & 4.1 \\
\hline \multirow{7}{*}{ Type of psychological violence* } & Kicks & 3 & 4.1 \\
\hline & Others & 10 & 13.5 \\
\hline & Offenses/Yells & 28 & 35.4 \\
\hline & Insults & 22 & 27.8 \\
\hline & Threat/Blackmail & 12 & 15.2 \\
\hline & Humiliation & 11 & 13.9 \\
\hline & Isolation from friends and family & 6 & 7.6 \\
\hline \multirow{3}{*}{ Negligence $^{*}$} & Care omission & 36 & 73.5 \\
\hline & Care deprivation of personal appearance & 9 & 18.4 \\
\hline & Arbitrary study deprivation & 4 & 8.2 \\
\hline \multirow{2}{*}{ Type of sexual violence* } & To submit to sexual caress & 4 & 57.1 \\
\hline & To force to have sex & 3 & 42.9 \\
\hline
\end{tabular}

Source: research database. ${ }^{*}$ Not informed if mother or father. ${ }^{* *} n \neq$ from 69 . The child or adolescent was victim of more than one type of violence.

institutional support. This was evident when one observes greater number of cases in the western area of Natal, known as an area of unfavorable socioeconomic conditions and with a significant number of children and adolescents in situations of social vulnerability and risk of illness and death [13].

The rise and persistence of cases of violence and prevalence of female victims are consistent with other studies about the subject, which show a higher frequency of violence among female children and adolescents [14] [15].

Other studies show a higher number of cases of abuse against children in an age group higher than the one found in this series. Thus, the violence to which children are exposed is inversely proportional to their age, based on the defense disability, long periods at home, physical and emotional fragility, and dependence on their parents and/ or caregivers, making them an easy target [5] [16].

The World Report on Violence and Health, 2002 [12], relates age and sex of children as factors that enhance vulnerability to child abuse. Regarding age, the indexes show that cases of physical abuse vary from country to country and in the case of sexual abuse, these rates tend to rise after the onset of puberty reaching the highest rates par- 
ticularly during adolescence, although also found in younger children. Regarding the victim's gender, its prevalence depends on the type of abuse, being girls 1.5 to 3 times more likely to abuse than boys, who, in turn, are more likely to severe physical punishment.

Several studies have identified a higher proportion of victims in lower social strata. The attackers are mainly family members or colleagues, especially parents [4] [14] [15]. For some authors, the association between family structure and well-being of children has been the subject of studies, especially in developed countries, where there are researches to measure the importance of family, education and parental behavior in quality of life, being determinant factors in physical and mental health of children [17].

In 2009, IBGE expanded its knowledge of different risk and protection factors to the health of adolescents through the National Health Research of the School, conducted with students from the ninth grade of elementary school in the cities and capitals and the Federal District. In relation to the family, it was shown that $58.3 \%$ of respondents lived in households with presence of both parents, $31.9 \%$ of the total lived only with their mothers, $4.6 \%$ lived only with their fathers and $5.2 \%$ lived without their parents in residence [13].

The parents' low educational attainment parents has been suggested by some authors as family/social risk factors associated with the occurrence of domestic violence [4]. There is no consensus in the literature about the predominant type of domestic violence; however, some authors refer to supremacy in physical violence [18]. Nevertheless, statistics from various municipalities, conducted by the Laboratory of Child Studies of the Institute of Psychology of the University of São Paulo [19] suggest different results, demonstrating, at first, negligence (41.1\%), followed by physical violence (31.0\%), psychological violence (16.6\%) and, finally, sexual assault (10.9\%). The data on domestic violence against children and adolescents obtained in SOS CHILD in Nat$\mathrm{al} / \mathrm{RN}$, in just three months in the second half of 2011, with 69 reported cases, show a significant demand for this event, highlighting the victim's fear to denounce, setting the "silence policy" of communities and family.

The greater visibility and severity of the problem and greater number of reporting by professionals from different services of reference and care to children and adolescents in Natal/RN/BR may explain the fact.

Violence against children and adolescents is a phenomenon that has accompanied the history of mankind and still seems to be rooted in contemporary societies. Patriarchy, gender violence, economic problems, ethnic and low education are some of the factors that have a close relationship with this kind of violence [15].

Regarding the affected anatomical structure or body site, many of the characteristics of the violent situations experienced by children and adolescents depends on the stage of their life cycle, time, place and social group [7]. Specialists in Legal Medicine claim that soft tissue lesions occur in $80 \%-100 \%$ of cases of domestic violence against children and adolescents. These data corroborate this study, highlighting the head as the main location for distribution of these lesions [20]. 
According to the results of the study on the increase in notification percentage performed by health professionals, among the reports, health professionals are those who most refer suspected and confirmed cases to SOS CHILD [21]. Among other causes, the creation of the Ministry of Health Ordinance [22] [23] may explain this fact, as it made mandatory the reporting by all health professionals of suspected and/or confirmed domestic and sexual violence, significantly contributing to break the "silence pact" in the context of abuse against children and adolescents.

Despite the advances in the legal field, such as the Adolescent and Child Laws and Ordinances of the Ministry of Health, studies also highlight a high under-reporting of violence, also considering it a problem that requires solution in Brazil. These studies point to the need for political and administrative decisions as the implementation of epidemiological surveillance activities that act in a more active and targeted manner in order to present positive results regarding the systematization and visibility of reported cases.

It is also emphasized the importance of constructing "Institutional Networks" that integrate existing services and with policies to enable funds to be allocated to vocational training in identifying, reporting and referring, concerning the cases, providing the implementation of effective strategies to interrupt the victimization cycle [18].

\section{Conclusions}

Besides favoring a particular view of the research population group, the epidemiological profile outlined with children and adolescents who are victims of domestic violence reveals a harsh reality, concluding that, regarding the epidemiological profile of the victims, female children and adolescents, experiencing early childhood, under the responsibility of parents, cared by female adolescent and young adults who use and abuse alcohol and other drugs, have more chances of suffering physical violence, followed by psychological and sexual abuse. The social-economic context and social vulnerability are also factors that influence on the chances of suffering any type of violence.

This study aimed to subsidize the formulation of a system to intervene, socially control and sensitize about the problem of violence against children and adolescents. From this effort, it intends to ensure the empowerment of state and civil society organizations that seek to develop strategies to promote safety and prevention/support to child and adolescent victims of intra- or extra-domestic violence in the most vulnerable areas.

Among other contributions, it also allows a diagnosis of the local reality to support the formulation of state projects and public policies to confront and prevent violence that compromises growth and healthy development of children and adolescents and that finally allows breaking the cycle of such violence.

This study presents some limitations, such as: coverage area; limited time and a small number of individuals researched; however, these elements do not imply less importance or relevance to the understanding of the violence phenomenon by the Protection Department of Natal/RN, Brazil. These evidences point for future studies and the implementation of an educational work along with people and/or SOS CHILD professionals. 
It is also emphasized the urgent need to create and integrate a support social network embedded in the proper context to interact, thus, may promote a culture of peace and prevention of violence grievance in a systematic way, with the support of institutions and sectors responsible for the care and protection of these victims.

\section{References}

[1] Marquetti, F.C. and Adorno, R.C.F. (2014) Discourses and Images of Violence. Revista Saúde e Sociedade, 23, 749-763. http://dx.doi.org/10.1590/S0104-12902014000300002 http://www.scielo.br/pdf/sausoc/v23n3/en_0104-1290-sausoc-23-3-0749.pdf

[2] Carvalho, D.W., Freire, M.T. and Vilar, G. (2012) Violence and the Media: The Case of Brazil. Revista Panamericana de Salud Pública, 31, 435-438.

http://dx.doi.org/10.1590/S1020-49892012000500012 http://www.scielosp.org/pdf/rpsp/v31n5/a12v31n5.pdf

[3] Bittar, D.B. and Nakano, A.M.S. (2011) Domestic Violence: Life History Analysis of Aggressive Mothers Users of Alcohol and Drugs in the Context of Their Original Families. Revista Texto \& Contexto Enfermagem, 20, 17-24. http://www.scielo.br/pdf/tce/v20n1/02.pdf

[4] Morais, R.L.G.L., Sales, Z.N., Rodrigues, V.P. and Oliveira, J.S. (2016) Actions of Protection for Children and Teenagers in Situations of Violence. Revista de Pesquisa Cuidado é Fundamemtal(Online), 8, 4472-4486. http://dx.doi.org/10.9789/2175-5361.2016.v8i2.4472-4486 http://www.seer.unirio.br/index.php/cuidadofundamental/article/view/4688/pdf_1901]

[5] Apostólico, M.R., Nóbrega, C.R., Guedes, R.N., Fonseca, R.M.G.S. and Egry, E.Y. (2012) Characteristics of Violence against Children in a Brazilian Capital. Revista Latino-Americana de Enfermagem, 20, 266-273. http://dx.doi.org/10.1590/S0104-11692012000200008 http://www.scielo.br/pdf/rlae/v20n2/08.pdf

[6] Roque, E.M.S.T., Ferriani, M.G.C., Gomes, R., Silva, L.M.P. and Carlos, D.M. (2014) Justice System and Secondary Victimization of Children and or Adolescents Victims of Sexual Violence in the Family. Revista Saúde e Sociedade, 23, 801-813.

http://dx.doi.org/10.1590/S0104-12902014000300006 http://www.scielo.br/pdf/sausoc/v23n3/0104-1290-sausoc-23-3-0801.pdf

[7] Waiselfisz, J.J. (2012) Mapa da violência 2012: crianças e adolescentes. FLACSO, Brasil.

[8] Brasil Ministério da Saúde. Secretaria de Vigilância em Saúde Departamento de Análise de Situação de Saúde (2011) Viva: Instrutivo de notificação de violência doméstica, sexual e outras. Ministério da Saúde, Brasil.

[9] Azevedo, M.A. and Guerra, V.N.A. (2005) Um cenário em (des) construção. In: UNICEF, Organizador, Direitos negados-A violência contra crianças e adolescentes no Brasil, UNICEF, Brasília (DF), 14-27. http://www.unicef.org/brazil/pt/Cap_01.pdf

[10] Pereira, M.G. (2007) Epidemiologia Teoria e Prática. Guanabara Koogan, São Paulo.

[11] World Health Organization (1986) Young People's Health-A Challenge for Society. Report of a WHO Study Group on Young People and Health for All, Technical Report Series 731, WHO, Geneva.

[12] World Health Organization (2002) World Report on Violence and Health. WHO, Geneva.

[13] Brasil Instituto Brasileiro de Geografia e Estatistica (IBGE) (2007) Síntese dos indicadores sociais: uma análise das condições de vida. Rio de Janeiro. http://biblioteca.ibge.gov.br/visualizacao/livros/liv36151.pdf

[14] Serafim, A.P., Saffi, F., Achá, M.F.F. and Barros, D.M. (2011) Demographic, Psychological and Behavioral Characteristics of Child and Adolescent Victims of Sexual Abuse. Revista de 
psiquiatria clínica, 4, 143-147. http://dx.doi.org/10.1590/S0101-60832011000400006

http://www.scielo.br/pdf/rpc/v38n4/a06v38n4.pdf

[15] Guimarães, J.A.T.L. and Villela, W.V. (2011) Characteristics of Physical and Sexual Violence against Children and Adolescents Examined at the Forensic Medicine Institute in Maceió, Alagoas State, Brazil. Cadernos de saúde pública, 27, 1647-1653.

http://dx.doi.org/10.1590/S0102-311X2011000800019

http://www.scielo.br/pdf/csp/v27n8/19.pdf

[16] Justino, L.C.L., Ferreira, S.R.P., Nunes, C.B., Barbosa, M.A.M., Gerk, M.A.S. and Freitas SLF. (2011) Sexual Violence against Adolescents: Notifications Filed in the Child and Adolescent Protective Services in the City of Campo Grande, State of Mato Grosso do Sul, Brazil. Revista Gaúcha de Enfermagem, 32, 781-787.

http://www.scielo.br/pdf/rgenf/v32n4/v32n4a20.pdf

[17] Assis, S.G., Avanci, J.Q., Pesce, R.P., Pires, T.O. and Gomes, D.L. (2012) Reports of Domestic, Sexual and Other Forms of Violence against Children in Brazil. Ciência \& Saúde Coletiva, 17, 2305-2317. http://dx.doi.org/10.1590/S1413-81232012000900012 http://www.scielo.br/pdf/csc/v17n9/a12v17n9.pdf

[18] Oliveira, J.R., Costa, C.O.M., Amaral, M.T.R., Santos, C.A., Assis, S.G. and Nascimento, O.C. (2014) Sexual Violence and Co-Occurrences Suffered by Children and Adolescents: Study of Incidents over a Decade. Ciência \& Saúde Coletiva, 19, 759-771. http://dx.doi.org/10.1590/1413-81232014193.18332013 http://www.scielo.br/pdf/csc/v19n3/1413-8123-csc-19-03-00759.pdf

[19] Laboratório de Estudos da Criança da USP (2007) A ponta do Iceberg: Pesquisando a violência doméstica contra crianças e adolescentes. www.ip.usp.br/laboratorios/lacri/iceberg.htm

[20] Paiva, C. and Zaher, V.L. (2012) Violence against Children: The Medical Care and the Expertise Assessment. Saúde, Ética \& Justiça, 17, 12-20. http://dx.doi.org/10.11606/issn.2317-2770.v17i1p12-20 http://www.revistas.usp.br/sej/article/view/45886/49489

[21] Veloso, M.M.X., Magalhães, C.M.C., Dell'Aglio, D.D., Cabral, I.R. and Gomes, M.M. (2013) Notification of Violence as a Strategy for Health Surveillance: Profile of a Metropolis in Brazil. Ciencia \& Saude Coletiva, 18, 1263-1272. http://dx.doi.org/10.1590/S1413-81232013000500011 http://www.scielo.br/pdf/csc/v18n5/11.pdf

[22] Brasil Ministério da Saúde (2001) Portaria GM/MS No. 1.968 de 25/10/2001. Notificação, ás autoridades competentes, de casos de suspeita ou confirmação de maus-tratos contra crianças e adolescentes atendidos nas entidades do Sistema Único de Saúde, Brasília.

[23] Brasil Ministério da Saúde (2014) Portaria No. 485 de 01/04/2014. Redefine o funcionamento do Serviço de atenção às Pessoas em Situação de Violência Sexual no âmbito do Sistema único de Saúde, Brasília. 
Submit or recommend next manuscript to SCIRP and we will provide best service for you:

Accepting pre-submission inquiries through Email, Facebook, LinkedIn, Twitter, etc. A wide selection of journals (inclusive of 9 subjects, more than 200 journals)

Providing 24-hour high-quality service

User-friendly online submission system

Fair and swift peer-review system

Efficient typesetting and proofreading procedure

Display of the result of downloads and visits, as well as the number of cited articles

Maximum dissemination of your research work

Submit your manuscript at: http://papersubmission.scirp.org/

Or contact ojn@scirp.org 